\title{
SNOMED-CT as a standardized language system model for nursing: an integrative review
}

\author{
SNOMED-CT como modelo de sistema de linguagem \\ padronizada à enfermagem: revisão integrativa \\ SNOMED-CT como modelo de sistema de lenguaje \\ estándar para enfermería: revisión integradora
}

\author{
Carolina Giordani da Silva ${ }^{a}$ \\ Edwing Alberto Urrea Vega ${ }^{a}$ \\ Fernanda Peixoto Cordova ${ }^{a, b}$ \\ Flávia Aline Carneiroc,d \\ Karina de Oliveira Azzolin ${ }^{a}$ \\ Lucas Henrique de Rosso ${ }^{a}$ \\ Murilo dos Santos Graeffa \\ Patrícia Vasconcellos de Carvalho ${ }^{c}$ \\ Miriam de Abreu Almeida ${ }^{a}$
}

How to cite this article:

Silva (G, Vega EAU, Cordova FP, Carneiro

FA, Azzolin KO, Rosso LH, Graeff MS,

Carvalho PV, Almeida MA. SNOMED-CT as a standardized language system model for nursing: an integrative review. Rev Gaúcha Enferm. 2020;41:e20190281. doi: https://doi.org/10.1590/19831447.2020.20190281
- Universidade Federal do Rio Grande do Sul (UFRGS). Programa de Pós-Graduação em Enfermagem. Porto Alegre, Rio Grande do Sul, Brasil.

${ }^{\mathrm{b}}$ Hospital de Clínicas de Porto Alegre (HCPA). Porto Alegre, Rio Grande do Sul, Brasil.

c Universidade Federal de Ciências da Saúde de Porto Alegre (UFCSPA). Porto Alegre, Rio Grande do Sul, Brasil.

${ }^{d}$ Conselho Regional de Enfermagem do Rio Grande do Sul (COREN/RS). Porto Alegre, Rio Grande do Sul, Brasil.

\section{ABSTRACT}

Objective: To describe the use of the Systematized Nomenclature of Medicine - Clinical Terms (SNOMED-CT) as a model for interoperability of the nursing terminology in the national and international contexts.

Methods: This is an integrative literature review according to Cooper, which searched for articles in Portuguese, English and Spanish, published between September 2011 and November 2018 in the BVS, PubMed, SCOPUS, CINAHL, EMBASE, and Web of Science databases, ending in a sample of 15 articles.

Results: The SNOMED-CT is a multi-professional nomenclature used by nursing in different care contexts, being associated with other standardized languages of the discipline, such as ICNP', NANDA-I, and the Omaha System.

Conclusion: This review has shown that the use of SNOMED- CT is incipient in the national context, justifying the need to develop studies aimed at mapping the interoperability of existing systems of standardized language, especially NANDA-I, ICNP and Omaha System, in order to adapt the implementation of SNOMED-CT.

Keywords: Nursing informatics. Standardized nursing terminology. Systematized Nomenclature of Medicine. Classification. Health information interoperability.

\section{RESUMO}

Objetivo: Descrever a utilização do Systematized Nomenclature of Medicine - Clinical Terms (SNOMED-CT) como modelo de interoperabilidade das terminologias da enfermagem no contexto nacional e internacional.

Metodologia: Trata-se de revisão integrativa da literatura segundo Cooper, que buscou artigos em português, inglês e espanhol, publicados entre setembro de 2011 a novembro de 2018 nas bases de dados BVS, PubMed, SCOPUS, CINAHL, EMBASE e Web of Science, finalizando em uma amostra de 15 artigos.

Resultados: 0 SNOMED-CT é uma nomenclatura multiprofissional utilizada pela enfermagem em diferentes contextos de cuidado, sendo associada com outras linguagens padronizadas da disciplina, como CIPE', NANDA-I e Omaha System.

Conclusão: Esta revisão mostrou que 0 uso do SNOMED-CT é incipiente no contexto nacional, justificando a necessidade de desenvolvimento de estudos visando o mapeamento dos sistemas de linguagem padronizadas existentes, especialmente a NANDA-I, CIPE e Omaha System, para fins de adequar a implementação do SNOMED-CT.

Palavras-chave: Informática em enfermagem. Terminologia padronizada em enfermagem. Systematized Nomenclature of Medicine. Classificação. Interoperabilidade da informação em saúde.

\section{RESUMEN}

Objetivo: Describir el uso de Systematized Nomenclature of Medicine - Clinical Terms (SNOMED-CT) como modelo de interoperabilidad de las terminologías de enfermería en el contexto nacional e internacional.

Metodología: Se trata de revisión integradora de la literatura según Cooper, que buscó estudios en portugués, inglés y español, publicados entre septiembre de 2011 y noviembre de 2018 en las bases de datos BVS, PubMed, SCOPUS, CINAHL, EMBASE y Web of Science, que culminó en una muestra de 15 artículos.

Resultados: SNOMED-CT es una nomenclatura multiprofesional empleada por la enfermería en diferentes contextos de cuidado, asociado a otros lenguajes estandarizados de enfermería como (IPE', NANDA-I y Omaha System.

Conclusión: Esta revisión demostró que el uso de SNOMED-CT es incipiente en el contexto nacional, lo que justifica la necesidad de desarrollar estudios destinados a mapear los sistemas de lenguajes estandarizados existentes, especialmente NANDA-I, CIPE y Omaha System, con el propósito de adaptar la implementación de SNOMED-CT.

Palabras clave: Informática aplicada a la enfermería. Terminología normalizada de enfermería. Systematized Nomenclature of Medicine. Clasificación. Interoperabilidad de la información en salud. 


\section{口INTRODUCTION}

The Systematized Nomenclature of Medicine - Clinical Terms (SNOMED-CT) is a nomenclature with clinical terms, organized and structured, composed of concepts, descriptions, correlations, and categories. This is a multi-axial nomenclature, which contains clinical data on health ${ }^{(1)}$. It results from the unification of the SNOMED Reference Terminology (SNOMED RT), developed by the American College of Pathologists (ACP), with Clinical Terms Version 3 (CTV3), known as Read Codes, maintained by the National Health Service (NHS) of the United Kingdom (2).

Its development began in 1965, including a nomenclature specialized in pathology; later, other Medicine fields were added. In 1976, other areas of health were included in the terminology; thus, it was structured in a multi-axial way, arranged in the following axes: topographic or anatomical; morphological; diagnosis; living organisms; chemical; physical agents, actions and forces; social context; occupations; and general. In an agreement signed in 1999, the entities made it possible to create a single terminology, SNOMED-CT, which became more complex with multiple possibilities to encode expressions. Thus, it became the most comprehensive and multilingual terminology in the world, currently with 340,659 active concepts ${ }^{(3-4)}$.

SNOMED-CT allows coding and relating concepts through multi-axial hierarchies ("one is one"type relationships), as well as logical definitions (attributes). The use of this correlation format enables greater expressiveness, allowing its use in the coding of information of individual patient care, in the generation of information appropriate to their care, in the integration with clinical guidelines and protocols, decision support systems and the exchange of information among different actors in the health care process ${ }^{(2)}$; it favors effective communication among the health teams for the sake of patient safety, makes it possible to measure the results of the provision of health services to the population, and fosters tools for the national management of health issues and resources ${ }^{(3)}$.

Following this worldwide trend in the standardization of terms and language that characterize the practice of different professions in the health area, nursing, in different contexts, has sought to standardize terms that configure their professional practice, with the nursing process (NP) as the protagonist in this scenario.

The NP is configured as a promising assistance tool. It structures clinical reasoning in five stages within a logical, simultaneous, dynamic, and most relevant sequence, which feedback to each other, namely: anamnesis and physical examination, nursing diagnosis, planning, implementation, and nursing evaluation ${ }^{(5-6)}$.

The language and structure with which the NP data is registered can be considered as an indication of the quality of the service provided ${ }^{(7)}$. In this perspective, the use of Standardized Language Systems (SLS) is relevant to the progress and visibility of nursing as a profession ${ }^{(8)}$.

The International Council of Nurses (ICN) considers it essential to use a universal SLS as a strategy for the qualification of nursing services and for the projection of the profession, since the development of a particular vocabulary promotes strengthening of the professional identity, organization of clinical reasoning, and improvement of the practice ${ }^{(8-9)}$.

In the global context, several SLS are employed by the nursing professionals(9). In Brazil, the most used in health, teaching, and research institutions are the Nursing Diagnosis (ND) Classification of NANDA International, Inc. (NANDA-I) ${ }^{(10)}$, Nursing Outcomes Classification (NOC) ${ }^{(11)}$, Nursing Interventions Classification (NIC) ${ }^{(12)}$, International Classification for Nursing Practice (ICNP) known as CIPE ${ }^{\circ(13)}$ in Brazil, from which the International Classification of Public Health Nursing Practices (CIPESC) was derived. It should be noted that the latter does not constitute another SLS(8).

With a view to enabling communication among different systems of standardized languages and protocols, in 2011 the Brazilian Ministry of Health (MS) published Ordinance No.2,073, which regulates the use of health information and interoperability for health information systems, determining that SNOMED-CT should be used for the codification of clinical terms, in all types of health institutions in the country, regardless of their nature, with the purpose of giving support for semantic interoperability among the computerized systems $s^{(3,10-14)}$.

However, the use of SNOMED-CT is not yet a reality in the Brazilian health institutions, mainly in the field of nursing, in which different terminologies are used in different regions of the country, with no homogeneity or interoperability in the use of these languages. In addition, no Brazilian studies were identified that addressed the relationship between SNOMED-CT and nursing, thus justifying the relevance of this study.

In view of the above, the following is questioned: "Is SNOMED-CT being used as a model for interoperability of the nursing terminologies in the national and international contexts? In this sense, the present study aims to describe the use of SNOMED-CT as interoperability model of the nursing terminologies in the national and international contexts. 


\section{METHOD}

This work was developed in the discipline of Research Methods in Standardized Language Systems in Nursing, of the Graduate Program in Nursing/UFRGS and it is an integrative literature review (ILR) study ${ }^{(11)}$, carried out in five stages, namely: formulation of the problem, collection, evaluation, analysis and interpretation of data, and presentation of the results ${ }^{(15)}$.

The guiding question of the research was the following: Is SNOMED-CT being used as a model for interoperability of the nursing terminologies in the national and international contexts?

The search was carried out from April to May 2019 in the Virtual Health Library (Biblioteca Virtual de Saúde, BVS), Medical Literature Analysis and Retrieval System Online (MEDLINE/PubMed), SCOPUS, Cumulative Index to Nursing and Allied Health Literature (CINAHL), Excerpta Medica Data-base (EMBASE), and Web of Science databases, for they use formal criteria to index the journals, thus configuring scientific criticality. The following controlled Health Sciences Descriptors (Descritores em Ciências da Saúde, DeCS) were used: "Nursing informatics", "Nursing Terminologies", and the Medical Subject Headings (MeSH): "Systematized Nomenclature of Medicine (SNOMED". The search strategy used in all the databases to minimize the risk of bias was the following: "SNOMED" AND "nursing informatics" OR "nursing terminologies".

The inclusion criteria used were the following: original articles, published in English, Spanish or Portuguese, available in online and free of charge, which answered the guiding question, published after the publication of Ordinance No.2,073, of August 31 1 st $2011^{(14)}$ until November 2018. The exclusion criteria were the following: articles that did not address the proposed theme, integrative and systematic reviews, theses, dissertations, and book chapters. Duplicate articles were counted only once.

An instrument was built to collect the information extracted from the studies, which contained the following data: title; year; authors; journal/database; country; type of study; language system; context; characterization of SNOMED-CT in the context of national and international nursing, and recommendations. Two researchers reviewed and classified the selected articles independently. For studies in which there was no agreement between the reviewers, a third examiner was required for evaluation.

Data analysis was performed from a synoptic table, allowing for the synthesis, comparison, and discussion of the findings in relation to the guiding question of the study, which contained the following information: authors, study objective and results - characterization (evidencing the particularities) of the use (interoperability) of SNOMED-CT in the context of national and international nursing. In addition, the levels of evidence for the selected articles were determined $^{(16)}$.

The results were described by means of frequency and percentage, presented in a chart, and discussed with the scientific literature in attention to the proposed objective.

The ethical aspects were respected by means of Law No.9,610/98 - Copyright Law ${ }^{(17)}$, referencing the appropriate authors and maintaining the authenticity of their ideas.

\section{RESULTS}

In the first stage of the research, 318 articles were identified. After applying the pre-established inclusion and exclusion criteria, 204 articles were deleted, 59 of which were repeated, as well as 145 articles that did not answer the guiding question (Figure 1). In the subsequent stage, the titles and abstracts of the 114 articles were read and, on this occasion, 85 articles that did not answer the guiding question were excluded. After this stage, 29 articles were read in full following the same evaluation process as the previous stage, which resulted in the exclusion of another 14 articles, and a final sample of 15 studies.

Chart 1 shows the characterization of the study sample.

In view of the data presented in Chart 1, it was observed that the United States of America was the country with the largest number of publications, with $66.6 \%$ (10) of the studies, followed by Denmark with 13.3\% (2). No Brazilian study was found in the time frame of this ILR. 2016, with $40 \%$ (6) of published research, was the most prevalent year.

Regarding the journals in which the studies were published, the Computers, Informatics, Nursing (CIN) and the Journal of Biomedical Informatics stand out with 20\% (3) of publications each. The cross-mapping research design for obtaining the results, in $66.6 \%$ (10) of the studies, was the most used. 


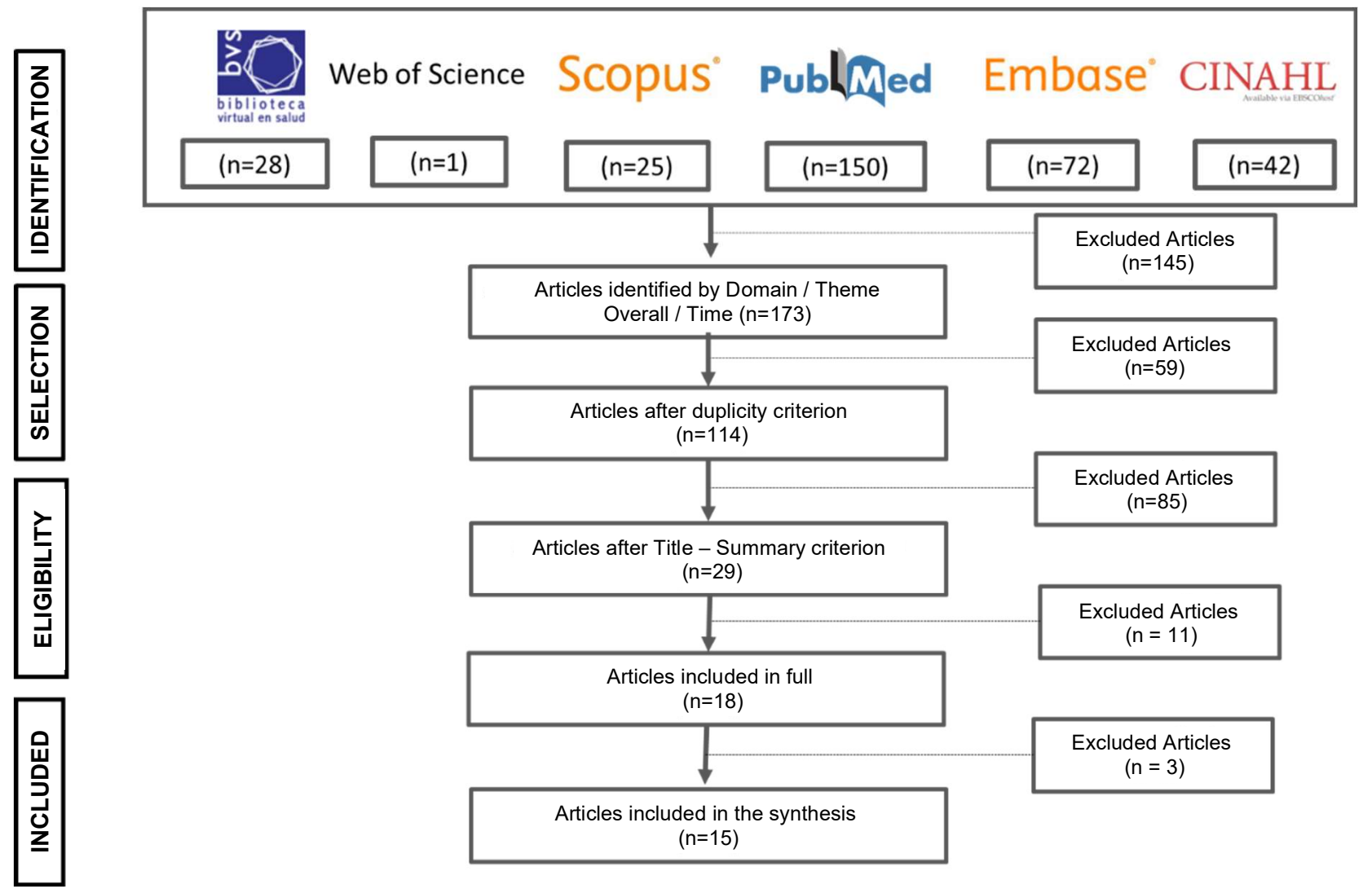

Figure 1 - Flowchart of the search system in the databases

Source: Research data, 2018.

\begin{tabular}{|l|l|l|l|}
\multicolumn{1}{|c|}{ Title/Author(s) } & \multicolumn{1}{c|}{$\begin{array}{c}\text { Country/Year/ } \\
\text { Journal }\end{array}$} & $\begin{array}{c}\text { Type of study/ } \\
\text { Objective } \\
\text { Level of Evidence }\end{array}$ \\
\hline $\begin{array}{l}\text { A Shovel-Ready Solution to } \\
\text { Fill the Nursing Data Gap in } \\
\text { the Interdisciplinary Clinical } \\
\text { Picture. } \\
\text { Keenan et. al(18) }\end{array}$ & $\begin{array}{l}\text { USA, 2018 } \\
\text { International } \\
\text { Journal of } \\
\text { Nursing Knowledge }\end{array}$ & $\begin{array}{l}\text { To critically evaluate 2014 American } \\
\text { Academy of Nursing (AAN) call-to- } \\
\text { action plan for generating interoperable } \\
\text { nursing data. }\end{array}$ & $\begin{array}{l}\text { Exploratory / } \\
\text { Level } 4\end{array}$ \\
\hline $\begin{array}{l}\text { Re-use of SNOMED-CT } \\
\text { subset in development } \\
\text { of the Danish national } \\
\text { standard for home care } \\
\text { nursing problems. } \\
\text { Højen, Gøeg, Elberg }{ }^{(19)}\end{array}$ & $\begin{array}{l}\text { Studies in Health } \\
\text { Technology } \\
\text { and Informatics }\end{array}$ & $\begin{array}{l}\text { To present the four step approach to } \\
\text { utilize existing SNOMED CT subsets for } \\
\text { development of subsets that suite a } \\
\text { specific clinical use case. }\end{array}$ & $\begin{array}{l}\text { Cross-mapping / } \\
\text { Level } 4\end{array}$ \\
\hline
\end{tabular}

Chart 1 - Characterization of the study sample 


\begin{tabular}{|c|c|c|c|}
\hline Title/Author(s) & $\begin{array}{l}\text { Country/Year/ } \\
\text { Journal }\end{array}$ & Objective & $\begin{array}{l}\text { Type of study/ } \\
\text { Level of Evidence }\end{array}$ \\
\hline $\begin{array}{l}\text { Standardizing Physiologic } \\
\text { Assessment Data to Enable } \\
\text { Big Data Analytics. } \\
\text { Matney et al }{ }^{(20)}\end{array}$ & $\begin{array}{l}\text { USA, } 2017 \\
\text { Western Journal of } \\
\text { Nursing Research }\end{array}$ & $\begin{array}{l}\text { To align a minimum set of physiological } \\
\text { nursing assessment data elements with } \\
\text { national standardized coding systems. }\end{array}$ & $\begin{array}{l}\text { Cross-mapping / } \\
\text { Level } 4\end{array}$ \\
\hline $\begin{array}{l}\text { Automating lexical } \\
\text { cross mapping of the } \\
\text { International Classification } \\
\text { for the Nursing } \\
\text { Practice (ICNP) to SNOMED- } \\
\text { CT. } \\
\text { Kim }^{(21)}\end{array}$ & $\begin{array}{l}\text { England, } 2016 \\
\text { Informatics } \\
\text { for Health \& } \\
\text { Social Care }\end{array}$ & $\begin{array}{l}\text { To examine the feasibility of automating } \\
\text { the lexical cross-mapping of a logic- } \\
\text { based nursing terminology (ICNP') for } \\
\text { SNOMED-CT using the Unified Medical } \\
\text { Language System (UMLS) maintained } \\
\text { by the National Library of Medicine. }\end{array}$ & $\begin{array}{l}\text { Cross-mapping / } \\
\text { Level } 4\end{array}$ \\
\hline $\begin{array}{l}\text { Mapping evidence-based } \\
\text { guidelines to standardized } \\
\text { nursing terminologies. } \\
\text { Dontje \& Coenen }\end{array}$ & $\begin{array}{l}\text { USA, } 2011 \\
\text { CIN: Computers, } \\
\text { Informatics, Nursing }\end{array}$ & $\begin{array}{l}\text { To describe the use of standardized } \\
\text { nursing terminologies to } \\
\text { represent evidence-based practice } \\
\text { recommendations for patients with } \\
\text { depression in primary care. }\end{array}$ & $\begin{array}{l}\text { Concept analysis / } \\
\text { Level } 4\end{array}$ \\
\hline $\begin{array}{l}\text { SNOMED-CT } \\
\text { implementation: } \\
\text { implications of choosing } \\
\text { clinical findings or } \\
\text { observable entities. } \\
\text { Rasmussen, Rosenbeck }\end{array}$ & $\begin{array}{l}\text { Denmark, } 2011 \\
\text { Studies in Health } \\
\text { Technology } \\
\text { and Informatics }\end{array}$ & $\begin{array}{l}\text { To analyse SNOMED CT implementation } \\
\text { in an Electronic Health Record (EHR). }\end{array}$ & $\begin{array}{l}\text { Cross-mapping / } \\
\text { Level } 4\end{array}$ \\
\hline $\begin{array}{l}\text { Mapping perinatal nursing } \\
\text { process measurement } \\
\text { concepts to standard } \\
\text { terminologies. } \\
\text { Ivory }\end{array}$ & $\begin{array}{l}\text { USA, } 2016 \\
\text { CIN: Computers, } \\
\text { Informatics, Nursing }\end{array}$ & $\begin{array}{l}\text { To determine which Perinatal Failure } \\
\text { to Rescue (P-FTR) data elements } \\
\text { were present in selected American } \\
\text { Nurses Association (ANA) recognized } \\
\text { standard terminologies. }\end{array}$ & $\begin{array}{l}\text { Cross-mapping / } \\
\text { Level } 4\end{array}$ \\
\hline $\begin{array}{l}\text { Communicating nursing } \\
\text { care using the health level } \\
\text { seven consolidated clinical } \\
\text { document architecture } \\
\text { release } 2 \text { care plan. } \\
\text { Matney, Dolin, } \\
\text { Buhl, Sheide }\end{array}$ & $\begin{array}{l}\text { USA, } 2016 \\
\text { CIN: Computers, } \\
\text { Informatics, Nursing }\end{array}$ & $\begin{array}{l}\text { To describe the Consolidated Clinical } \\
\text { Document Architecture (C-CDA), } \\
\text { introduces LOINC and SNOMED } \\
\text { CT, discusses how the C-CDA Care } \\
\text { Plan aligns with the nursing process, } \\
\text { and illustrates how nursing care data } \\
\text { can be structured and encoded within } \\
\text { a C-CDA Care Plan. }\end{array}$ & $\begin{array}{l}\text { Description / } \\
\text { Level } 4\end{array}$ \\
\hline $\begin{array}{l}\text { Mapping wound } \\
\text { assessment data elements } \\
\text { in SNOMED-CT. } \\
\text { Block, Handfield }\end{array}$ & $\begin{array}{l}\text { Canada, } 2016 \\
\text { Nursing Informatics }\end{array}$ & $\begin{array}{l}\text { To present the mapping activity of } \\
\text { wound assessment data elements } \\
\text { to SNOMED-CT. }\end{array}$ & $\begin{array}{l}\text { Cross-mapping / } \\
\text { Level } 4\end{array}$ \\
\hline
\end{tabular}

Chart 1 - Cont. 


\begin{tabular}{|c|c|c|c|}
\hline Title/Author(s) & $\begin{array}{l}\text { Country/Year/ } \\
\text { Journal }\end{array}$ & Objective & $\begin{array}{l}\text { Type of study/ } \\
\text { Level of Evidence }\end{array}$ \\
\hline $\begin{array}{l}\text { Development of the nursing } \\
\text { problem list subset of } \\
\text { SNOMED-CT. } \\
\text { Matney, Warren, Evans, } \\
\text { Kim, Coenen (27) }\end{array}$ & $\begin{array}{l}\text { USA, } 2012 \\
\text { Journal of } \\
\text { Biomedical Informatics }\end{array}$ & $\begin{array}{l}\text { To create an interoperable set of ND } \\
\text { for use in the patient's problem list in } \\
\text { the Electronic Health Records (EHR) to } \\
\text { support interoperability. }\end{array}$ & $\begin{array}{l}\text { Cross-mapping / } \\
\text { Level } 4\end{array}$ \\
\hline $\begin{array}{l}\text { Interterminology mapping } \\
\text { of nursing problems. } \\
\text { Kim, Hardiker, Coenen }{ }^{(28)}\end{array}$ & $\begin{array}{l}\text { USA, } 2014 \\
\text { Journal of } \\
\text { Biomedical Informatics }\end{array}$ & $\begin{array}{l}\text { To determine the degree of overlap } \\
\text { between ICNP` and SNOMED-CT, with } \\
\text { a focus on nursing problems, as a first } \\
\text { step towards harmonization between } \\
\text { the two terminologies. }\end{array}$ & $\begin{array}{l}\text { Cross-mapping / } \\
\text { Level } 4\end{array}$ \\
\hline $\begin{array}{l}\text { Rigor in electronic health } \\
\text { record knowledge } \\
\text { representation: Lessons } \\
\text { learned from a SNOMED- } \\
\text { CT clinical content } \\
\text { encoding exercise. } \\
\text { Monsen, Finn, Fleming, } \\
\text { Garner, LaValla(29) }\end{array}$ & $\begin{array}{l}\text { USA, } 2014 \\
\text { Informatics } \\
\text { for Health \& } \\
\text { Social Care }\end{array}$ & $\begin{array}{l}\text { To educate clinicians and students } \\
\text { about knowledge representation and } \\
\text { to evaluate their success of applying } \\
\text { the manual lookups method for } \\
\text { assigning Systematized Nomenclature } \\
\text { of Medicine Clinical Terms (SNOMED } \\
\text { CT) concept identifiers using formally } \\
\text { mapped concepts from the Omaha } \\
\text { System interface terminology. }\end{array}$ & $\begin{array}{l}\text { Cross-mapping / } \\
\text { Level } 4\end{array}$ \\
\hline $\begin{array}{l}\text { Toward Improving Quality of } \\
\text { End-of-Life Care: Encoding } \\
\text { Clinical Guidelines and } \\
\text { Standing Orders Using the } \\
\text { Omaha System. } \\
\text { Slipka, Monsen }{ }^{(30)}\end{array}$ & $\begin{array}{l}\text { USA, } 2018 \\
\text { Worldviews } \\
\text { on Evidence } \\
\text { Based Nursing }\end{array}$ & $\begin{array}{l}\text { To investigate the feasibility of using } \\
\text { the Omaha System as a framework } \\
\text { for encoding interoperable evidence- } \\
\text { based EOL interventions with specified } \\
\text { temporality for use across disciplines } \\
\text { and settings. }\end{array}$ & $\begin{array}{l}\text { Retrospective } \\
\text { study / Level } 4\end{array}$ \\
\hline $\begin{array}{l}\text { Harmonising ICNP and } \\
\text { SNOMED-CT: A model for } \\
\text { effective collaboration. } \\
\text { Hardiker }{ }^{(31)}\end{array}$ & $\begin{array}{l}\text { United } \\
\text { Kingdom, } 2016 \\
\text { Nursing Informatics }\end{array}$ & $\begin{array}{l}\text { To demonstrate an approach to } \\
\text { collaborative working within nursing } \\
\text { and health informatics. }\end{array}$ & $\begin{array}{l}\text { Experience report } \\
\text { / Level } 5\end{array}$ \\
\hline $\begin{array}{l}\text { Semantic mappings and } \\
\text { locality of nursing diagnostic } \\
\text { concepts in UMLS. } \\
\text { Kim, Coenen, Hardiker }{ }^{(32)}\end{array}$ & $\begin{array}{l}\text { USA, } 2012 \\
\text { Journal of } \\
\text { Biomedical Informatics }\end{array}$ & $\begin{array}{l}\text { To determine the concordance } \\
\text { of semantic mappings of the selected } \\
\text { diagnostic concepts in the unified } \\
\text { framework; to exploit synonymous } \\
\text { relationships of diagnostic concepts } \\
\text { across the source terminologies; } \\
\text { and to explore the placement of the } \\
\text { selected nursing concepts on the } \\
\text { UMLS Semantic Network. }\end{array}$ & $\begin{array}{l}\text { Cross-mapping / } \\
\text { Level } 4\end{array}$ \\
\hline
\end{tabular}

Chart 1 - Cont

Source: Authors. 


\section{DISCUSSION}

SNOMED-CT is an important clinical nomenclature for nursing care and the use of classification systems, paving the way for the dissemination of electronic records and the integration of different levels of care in the Unified Health System (Sistema Único de Saúde, SUS).

This integrative literature review study showed that SNOMED-CT has been being used by nursing in different care contexts, such as the hospital setting, home care, and primary care, aiming to build a standardized language to help the nurses' decision-making in patient care, although still in an incipient way, mainly with regard to scientific studies. In this sense, studies have been carried out to determine its effectiveness and applicability ${ }^{(9,26,30,32)}$.

In addition, studies have been developed associating the use of this clinical nomenclature with other standardized languages used by nursing, such as Logical Observation Identifiers, Names, and Codes (LOINC), ICNP', NANDA-I, and Omaha System, as well as other health information platforms like Unified Medical Language System (UMLS) $)^{(18,20-21,25,27-30)}$. This demonstrates an effort that the discipline, in different countries, has made in an attempt to find a system that better contemplates its practice.

LOINC is a standards set terminology designed for use in the USA federal government systems for the electronic exchange of clinical health information, as it refers to laboratory tests on transactions between health facilities. LOINC and SNOMED-CT are contained in the 10 terminologies or classifications recognized by the American Nurses Association (ANA) as standards that apply to the nursing practice ${ }^{(25)}$. The use of standard terminologies facilitates semantic interoperability and models based on standards and incorporated into hospital electronic records. These models can promote decision-making in real time, capturing and organizing information without compromising the nurse's workflow ${ }^{(23)}$. In addition, it contributes to collaboration in care, automated communication between nurses and other health professionals, determining effective nursing interventions and identifying evidence-based practices, which can be used in the construction of computerized clinical systems for assisting nurses' decision-making in the care of patients ${ }^{21,23)}$.

ICNP is a standardized terminology developed by nurses, which is used in several countries to systematically describe and report the nursing practice. Although there are obvious benefits to being able to consistently capture the nursing practice, it is important to recognize that nurses do not exercise their practice in isolation.

With this in mind, the ICN is committed to ensuring that nurses act together with other disciplines, as well as they remain connected to the global informatics landscape, actively contributing to the construction and feeding of these SLS. Part of this commitment is manifested in the form of a formal collaboration between the ICN and the International Health Terminology Standards Development Organisation (IHTSDO), which seeks to ensure the alignment between ICNP' and SNOMED-CT(21).

In common with ICNP', SNOMED-CT is also supported by the logic of the description and organized in a tree structure with 19 top-level concepts (hierarchies). This provided a tangible first step towards harmonizing nursing content in both terminologies, by examining the degree to which the NDs and the ICNP results ${ }^{\circ}$ had equivalent or corresponding concepts in SNOMED-CT. It was demonstrated that, when using the previous releases, which were 238 ICNP $^{\circ}$ concepts (2013 version), 93.3\% (222) of the diagnosis statements and results have mappings for SNOMED-CT ${ }^{(28)}$

While more research studies are needed to improve the matching method, the combination of cross-mappings is useful for terminology developers. The great part of the combined concepts, when cross-mapping was performed, was lexically similar between ICNP and SNOMED-CT. However, some semantic incompatibilities have also been observed, requiring caution when using the automated procedure alone ${ }^{(20)}$.

Thus, a team of researchers from both terminologies has been working on an equivalence table for NDs or "problems" and a similar table for nursing interventions. The potential benefits of these tables are far-reaching: they provide a means to transform ICNP' encoded data into SNOMED-CT and vice versa (for example, an ICNP' concept in a local system can be converted through the table into the SNOMED-CT equivalent concept for its use in a multidisciplinary record). The added value of the work included improvements in both terminologies and significant additional nursing content, including 120 new clinical findings for SNOMED-CT ${ }^{(21)}$.

In this sense, studies ${ }^{(27,30)}$ were also carried out in the initial stages of development of SNOMED-CT for mapping with other standardized nursing languages. Attempts were made through the American College of Pathologists (ACP) to harmonize with a number of nursing terminologies, which had been recognized by the ANA, including NANDA-(10).

The nursing content was not al ways available in SNOMED$\mathrm{CT}$ at the time of the harmonization activity, with new content being added until mappings could be made from the original terminology ${ }^{(27)}$. There are numerous specialized collections of SNOMED-CT concepts that support the entry of clinical data in electronic hospital records, such as NANDA-1(32); however, cross-mapping studies between SNOMED-CT and NANDA-I, NIC, NOC, and ICNP' were not identified in this 
study because they were carried out in years before the established time frame ${ }^{(33-36)}$.

Mapping studies have also been carried out between SNOMED-CT and the Omaha System, which consists of the problem classification scheme (ND), intervention, and problem classification scale for results, with a focus on community health. This approach establishes a framework for describing multidisciplinary evidence-based interventions, temporally specified, across the continuum of care. There is potential to improve health care across different scenarios and populations from the implementation of evidence-based guidelines. This favors efficiency of communication and of care provision. The electronic health records based on the Omaha System are used by tens of thousands of clinicians worldwide. It is one of the 12 terminologies recognized by the ANA (2012) and is mapped to SNOMED-CT(30).

Post-graduate nursing students, experienced clinicians, performed 21 cross-mappings of the Omaha System terms in SNOMED-CT, of which $57.1 \%$ (12) were successful. The reports indicated that success in the manual search method was more likely when there was an exact match of the Omaha System term with the description of SNOMED-CT ${ }^{(30)}$.

In the cross-mapping, another analysis of the Omaha System showed that 810 concepts were mapped with the SNOMED-CT concepts. The purpose of incorporating multiple interfaces of terminologies, structured vocabularies, and standards within SNOMED-CT is to create a common reference terminology for use in electronic hospital records, with the aim of facilitating the transfer of meaningful information between the hospital's multidisciplinary team and community health ${ }^{(30)}$.

Efforts are being made to integrate the aforementioned nursing terminologies with the SNOMED-CT. One solution to improve the interoperability between these information systems was to add them to the UMLS designed by the US National Library of Medicine. UMLS is a tool that contains cross-mappings of several terminologies in a unified structure ${ }^{(21,32)}$.

The evaluation of the UMLS semantic mappings was performed by measuring its proportion of concordance with the mappings of different specialists in the health disciplines. The study showed that the mappings between the UMLS and NANDA-I concepts for SNOMED-CT were highly consistent with the mappings of experts. The level of concordance in the ICNP' mappings for SNOMED-CT, and NANDA-I in UMLS was relatively low, indicating the need for more research and development. Likewise, the semantic location of the ICNP concepts could be improved ${ }^{(27,32)}$.

\section{GINAL CONSIDERATIONS}

In the international context, it was identified that the use of the SNOMED-CT model has been carried out through the development of mapping studies, aiming at the interoperability of the existing SLSs, especially NANDA-I, ICNP', and the Omaha System, for the purpose of adapting the implementation of SNOMED-CT in the clinical context of nursing. At the national level, however, the failure to identify Brazilian studies in this ILR shows that the interoperability between the SLSs and SNOMED-CT is still a distant reality for nursing, given the low scientific production on this theme.

The limitation of this study was the time frame used and the inclusion in the sample only of articles with online and free access, which may justify the small number of studies found, including Brazilian ones. Thus, it is suggested to expand the studies to better understand the interoperability of SNOMED-CT with the SLS in nursing, in the Brazilian context, in view of the determination of the 2011 MS Ordinance and of the importance of communication among the professionals who are part of the health teams.

The Brazilian Health System needs to consolidate the use of this nomenclature to optimize the provision of health services in the care of users, since this system advocates interdisciplinarity, that is, the records are performed by each professional category that provides care, but it will be understood and comprehensive to all the professional groups.

The use of SNOMED-CT during the training of health professionals, especially in nursing, can be a relevant and necessary strategy to enable the use of this nomenclature in the clinical practice, since not all health professions have SLSs that represent their discipline. 


\section{REFERENCES}

1. Shahpori R, Doig C. Systematized Nomenclature of Medicine-Clinical Terms direction and its implications on critical care. J Crit Care. 2010;25(2):364.e1-9. doi: https://doi.org/10.1016/j.jcrc.2009.08.008

2. Maciel DA, Ferreira DP, Marin HF. Padrões de terminologias nacionais para procedimentos e intervenções na saúde. Rev Adm Saúde. 2018;18:71. doi: https://doi.org/10.23973/ras.71.111

3. Araujo TV, Pires SR, Bandiera-Paiva P. Adoção de padrões para Registro Eletrônico em Saúde no Brasil. RECIIS Rev Eletron Comun Inf Inov Saúde. 2014;8(4):55466. doi: https://doi.org/10.3395/reciis.v8i4.895.pt

4. Snomed.org [Internet]. London: SNOMED International; c2018 [cited 2019 Jul 23]. Available from: http://www.snomed.org/

5. Conselho Federal de Enfermagem (BR). Resolução Cofen no 358/2009. Sistematização da Assistência de Enfermagem e a implementação do Processo de Enfermagem em ambientes, públicos ou privados, em que ocorre 0 cuidado profissional de Enfermagem. Brasíla; 2009 [citado 2020 Jan 10]. Disponivel em: http://www.cofen.gov.br/resoluo-cofen-3582009_4384. html

6. Gutiérrez MGR, Morais SCRV. Systematization of nursing care and the formation of professional identity. Rev Bras Enferm. 2017;70(2):436-41. doi: https://doi. org/10.1590/0034-7167-2016-0515

7. Carvalho EC, Cruz DALM, Herdman TH. Contribuição das linguagens padronizadas para a produção do conhecimento, raciocínio clínico e prática clínica da Enfermagem. Rev Bras Enferm. 2013;66(spe):13-41. doi: https://doi. org/10.1590/S0034-71672013000700017

8. Figueira MCES, Jacob LMDS, Spazapan MP, Chiquetto L, Rolim ACA, Duran ECM, et al. Reflexões sobre a utilização da CIPE na prática profissional: revisão integrativa. Rev Enferm Atenção Saúde. 2018;7(2). doi: https://doi. org/10.18554/reas.v7i2.2369

9. Gómez-Salgado J, Jacobsohn L, Frade F, Romero-Martin M, Ruiz-Frutos C. Applying the WHO International Classification of Functioning, Disability and Health in Nursing Assessment of Population Health. Int J Environ Res Public Health. 2018;15(10):2245. doi: https://doi.org/10.3390/ijerph15102245

10. Herdman TH, Kamitsuru S. Diagnósticos de Enfermagem da Nanda: definições e classificações 2018-2020. 11 ed. Porto Alegre: Artmed; 2018.

11. Moorhead S, Johnson M, Maas ML, Swanson E. NOC Classificação dos resultados de enfermagem. $4^{\mathrm{a}}$ ed. Rio de Janeiro: Elsevier; 2010.

12. Bulechek GM et al. Classificação das intervenções de enfermagem (NIC) - $6^{\text {a }}$ ed.- Rio de Janeiro: Elsevier, 2016.

13. Garcia TR, Coenen AM, Bartz CC, organizadoras. Classificação internacional para a prática de enfermagem CIPE : versão 2017. Porto Alegre: Artmed; 2018.

14. Ministério da Saúde (BR). Portaria № 2.073, de 31 de agosto de 2011. Regulamenta 0 uso de padrões de interoperabilidadee informação em saúdeno Âmbito do Sistema Único de Saúde, nos níveis Municipal, Distrital, Estadual e Federal, e para os sistemas privados e do setor de saúde suplementar. Brasília; 2011 [citado 2019 jul 23]. Disponível em: http://bvsms.saude.gov.br/bvs/ saudelegis/gm/2011/prt2073_31_08_2011.html

15. Cooper HM. Interating research: a guide for literature reviews. $2^{\text {nd }}$ ed. Newbury Park: Sage; 1989.

16. Souza M, Silva M, Carvalho R. Revisão integrativa: o que é e como fazer. Einstein. 2010;8(1Pt1):102-6. doi: https://doi.org/10.1590/s1679-45082010rw1134
17. Presidência da República (BR). Lei no 9.610, de 19 de fevereiro de 1998. Brasília;1998 [citado 2019 jul 23]. Disponível em: http://www.planalto.gov.br/ ccivil_03/leis/L9610.htm

18. Keenan GM, Lopez KD, Sousa VEC, Stifter J, Macieira TGR, Boyd AD, et al. A shovel-ready solution to fill the nursing data gap in the interdisciplinary clinical picture. Int J Nurs Knowl. 2018 Jan;29(1):49-58. doi: http://doi.wiley. com/10.1111/2047-3095.12168

19. Højen AR, Gøeg KR, Elberg PB. Re-use of SNOMED-CT subset in development of the Danish national standard forhome care nursing problems. Stud HealthTechnol Inform. 2015;210:140-4. https://doi.org/10.3233/978-1-61499-512-8-140

20. Matney SA, Settergren T, Carrington JM, Richesson RL, Sheide A, Westra BL. Standardizing physiologic assessment data to enable big data analytics. West J Nurs Res. 2017 Jan;39(1):63-77. doi: https://doi. org/10.1177/0193945916659471

21. Kim TY. Automating lexical cross-mapping of ICNP to SNOMED CT. Informatics Heal Soc Care. 2016 Jan;41(1):64-77. doi: https://doi.org/10.3109/17538157. 2014.948173

22. Dontje K, Coenen A. Mapping evidence-based guidelines to standardized nursing terminologies. Comput Inform Nurs. 2011 Dec;29(12):698-705. doi: https://doi.org/10.1097/NCN.0b013e31822b84e6

23. Rasmussen AR, Rosenbeck K. SNOMED CT implementation: implications of choosing clinical findings or observable entities. Stud Health Technol Inform. 2011;169:809-13. doi: https://doi.org/10.3233/978-1-60750-806-9-809

24. Ivory CH. Mapping perinatal nursing process measurement concepts to standard terminologies. Comput Inform Nurs. 2016 Jul;34(7):312-20. doi: https://doi. org/10.1097/CIN.0000000000000243

25. Matney SA, Dolin G, Buhl L, Sheide A. Communicating nursing care using the health level seven consolidated clinical document architecture release 2 care plan. Comput Inform Nurs. 2016 Mar;34(3):128-36. doi: https://doi. org/10.1097/CIN.0000000000000214

26. Block L, Handfield S. Mapping wound assessment data elements in SNOMED CT. Stud Health Technol Inform. 2016;225:1078-9. doi: https://doi. org/10.3233/978-1-61499-658-3-1078

27. Matney SA, Warren JJ, Evans JL, Kim TY, Coenen A, Auld VA. Development of the nursing problem list subset of SNOMED CT ${ }^{\odot}$. J Biomed Inform. 2012 Aug;45(4):683-8. doi: https://doi.org/10.1016/j.jbi.2011.12.003

28. Kim TY, Hardiker N, Coenen A. Inter-terminology mapping of nursing problems. J Biomed Inform. 2014 Jun;49:213-20. doi: https://doi.org/10.1016/j. jbi.2014.03.001

29. Monsen KA, Finn RS, Fleming TE, Garner EJ, Lavalla AJ, Riemer JG. Rigor in electronic health record knowledge representation: lessons learned from a SNOMED CT clinical content encoding exercise. Informatics Heal Soc Care. 2014 Oct;41(2):1-15. doi: https://doi.org/10.3109/17538157.2014.965302

30. Slipka AF, Monsen KA. Toward improving quality of end-of-life care: encoding clinical guidelines and standing orders using the Omaha System. Worldviews Evid Based Nurs. 2018 Feb;15(1):26-37. doi: https://doi.org/10.1111/ wvn. 12248

31. Hardiker N. Harmonising ICNP and SNOMED-CT: a model for effective collaboration. studies in health technology and informatics. 2016 Jan;225:7445. doi: https://doi.org/10.3233/978-1-61499-658-3-744

32. Kim TY, Coenen A, Hardiker N. Semantic mappings and locality of nursing diagnostic concepts in UMLS. J Biomed Inform. 2012 Feb;45(1):93-100. doi: https://doi.org/10.1016/j.jbi.2011.09.002 
33. Park HT, Lu DF, Konicek D, Delaney C. nursing interventions classification in systematized nomenclature of medicine clinical terms: a cross-mapping validation. Comput Inform Nurs. 2007;25(4):209-10. doi: https://doi. org/10.1097/01.NCN.0000280590.35690.7d

34. Lu DF, Park HT, Ucharattana P, Konicek D, Delaney C. Nursing Outcomes Classification in the Systematized Nomenclature of Medicine Clinical Terms: a cross-mapping validation. Comput Inform Nurs. 2007;25(3):159-70. doi: https://doi.org/10.1097/01.NCN.0000270042.22164.21
35. Lu DF, Eichmann D, Konicek D, Park HT, Ucharattana P, Delaney C. Standardized Nursing Language in the Systematized Nomenclature of Medicine Clinical Terms: a cross-mapping validation method. Comput Inform Nurs. 2006;24(5):288-96. doi: https://doi.org/10.1097/00024665-200609000-00011

36. Lundberg C, Park HT, Coenen A. Making connections: Systematized Nomenclature of Medicine-Clinical Terms (SNOMED CT) and International Classification for Nursing Practice ICNP) (PaperPresentation).ComputInform Nurs. 2008;26(5):301. doi: https://doi.org/10.1097/01.NCN.0000304827.47262.88

- Corresponding author:

Carolina Giordani da Silva

E-mail: carol.giordani@gmail.com

\section{Associate editor:}

Graziella Badin Aliti

Editor-in-chief:

Approved: 03.18.2020 